\title{
A Draft Northeast Asia Nuclear- Weapon-Free Zone Treaty: A Basis for Discussion
}

\author{
By Hiromichi Umebayashi (Japan)
}

\begin{abstract}
irst of all, I would like to express my deepest thanks to host - organizations of this great conference for giving me a precious 1 opportunity to be here in Mongolia and speak on the topic of vital importance of the Northeast Asia Nuclear-Weapons-Free Zone (NEA-NWFZ) . It is my special honor and pleasure to talk on this topic in Mongolia, a sole internationally recognized single state NWFZ. In this respect, my gratitude goes to all the Mongolian participants, especially friends from Blue Banner, including Ambassador Enkhsaikhan, the key organizer of this conference.
\end{abstract}

\section{Situation after the DPRK Nuclear Test}

Before entering the details of my presentation, I want to mention my personal view briefly on the situation of the Six Party Talks on the denuclearization of the Korean Peninsula after the 2006 October nuclear test by the Democratic People's Republic of Korea (DPRK). The nuclear explosion test by the DPRK was a serious setback for the regional peace and security, but the $3^{\text {rd }}$ session of the $5^{\text {th }}$ Six Party Talks, which started on February $8^{\text {th }} 2007$, restored the lost path leading to the denuclearization of the Korean Peninsula, as it agreed to the initial actions to implement the Joint Statement of September 19th 2005. This historic Joint Statement states "The six parties unanimously reaffirmed that the goal of the six-party talks is the verifiable denuclearization of the Korean Peninsula in a peaceful manner," and "The DPRK committed to abandoning all nuclear programs and returning at an early date to the NPT and to the IAEA safeguards." Also the Joint Statement confirmed 
that "The 1992 joint declaration of the denuclearization of the Korean peninsula should be observed and implemented." Therefore, despite the progress of the initial actions has been very slow since because of the unexpected hardships in the handling of the DPRK' s fund frozen in Banco Delta Asia, we can say we are now on the right track.

Another point to be emphasized at this point is that it is all the more imperative that nuclear threats from any country should equally eliminated and confidence of freedom from the nuclear threats are impartially shared by all parties in this region. Recent developments, in which some observers in Japan and Republic of Korea (ROK) argued for the possible nuclear armament of Japan and the ROK, have clearly demonstrated the necessity that the notion of the national security resting on the nuclear arms must be universally prohibited in this region. Namely, it is high time for us to pursue the way toward a Northeast Asia NuclearWeapon-Free Zone (NEA-NWFZ) .

\section{The Three-Plus-Three Arrangement}

Please take a look at the chronology table on the last page of my paper. After the Cold War, a Northeast Asia NWFZ became more than a political slogan. Several concrete proposals appeared as you see in the table. We have already listened to the two speakers who are pioneers in these efforts: Mr. Bernard Gourley from Professor Endicott's group, and Professor Kumao Kaneko presented his views including his pioneering works. Learning these efforts and lessons, we proposed a so-called "three-plus-three" arrangement of a NEA-NWFZ in 1996 as a feasible and attainable approach. Eventually we proposed a Model Treaty based on this arrangement at a workshop in the UN Headquarters in New York, in cooperation with the ROK NGOs, with guest commentators including Prof. Kaneko in 2004.

When we introduced the three-plus-three arrangement for the first time, there existed no Six Party Talk yet on the denuclearization of the Korean Peninsula. But we believed that in contemplating the situation in Northeast Asia, this approach would be most realistic because it recognizes the fundamental composition of the nations involved; namely the DPRK, the ROK and Japan could take on the leading role in establishing a geographical nuclear weapon-free zone, and the U.S., Russia and China could support these countries as nuclear-weapon states 
with strong security interests in the region. It is no accident that these six nations became the members of the later Six Party Talks.

One of the merits with the three-plus-three arrangement is the three non-nuclear weapon states can base their participation on their present declared policies. In other words, the DPRK and the ROK can build on the foundation of the Joint Declaration of the Denuclearization of the Korean Peninsula, which went into effect in 1992. The validity of the Declaration was reaffirmed in February 2007, as I explained before. On the part of Japan, it has its three non-nuclear principles (no production, no possession, and no introduction of nuclear weapons) and its Atomic Energy Basic Law prohibiting the military use of atomic energy (1955) . These could easily be extended to support a nuclear weapon-free zone.

\section{A Model Treaty}

The Model Treaty is by no means a finished document, but a basis for further discussions and deliberations. The full text can be read at the following URL.http://www.peacedepot.org/e-news/workingpaperl.pdf . I want to explain some of its features and remaining issues.

\section{(1) Six-Nation Treaty}

The treaty would be signed by six nations with a three plus three structure. The parties to the Treaty would be placed in two categories: "Intrazonal States" (Japan, DPRK, ROK) and "Neighboring Nuclear Weapon States" (China, Russia, U.S.) . Geographically, the NEA-NWFZ is composed of the territory of the former category of States. The two categories of states parties have different fundamental obligations under the treaty.

\section{2) Obligations of the Intrazonal States}

In addition to obligations cormon to the existing NWFZ treaties, such as the prohibition of development, test, production or possession of nuclear weapons, the Model Treaty has introduced two unique obligations: "To eliminate all dependence whatsoever on any nuclear weapon or any other nuclear explosive device in all aspects of its security policy," and "To exert effort for the diffusion of education worldwide with regard to the urgency of nuclear disarmament, including the transmission to the present and future generations of the facts on the damage inflicted on the citizens and cities by the atomic bombs dropped 
in 1945." The former is a progressive challenge and will be discussed more in my separate presentation in the aftemoon session. The latter is reflecting the regional characteristic of the northeast Asia that is the only region of the entire world where nuclear weapons have been used in reality. In light of the fact that the Intrazonal States are home to many A-bomb survivors, the treaty includes this obligation to educate coming generations regarding nuclear disarmament and the damage to humans and societies inflicted by nuclear weapons.

(3) Obligations of the Neighboring Nuclear Weapon States Security Assurances Built into the Treaty Booly

Existing nuclear weapon-free zone treaties include negative security assurance, the assurance for nuclear weapon states not to use or threaten to use such weapons against non-nuclear states within the Zone, as clauses in the protocol. In contrast, in the Model Treaty, they are incorporated as requirements of the treaty itself because the Neighboring Nuclear Weapon States are closely involved in the regional security and the security assurances are considered to be one of the central concems to be addressed in a NEA-NWFZ treaty.

(4) Prior Consultation Arrangement for Transits or Calls of Ships and Planes

All the existing NWFZ treaties leave the problem of ships or planes suspected of carrying muclear weapons entering ports or passing through sea or air territory up to the individual parties directly involved. Considering past protracted controversies on this subject, the Model Treaty takes example by existing treaties, but takes it a step further and incorporates an obligation of prior consultation in all such situations in advance. Permission or denial of permission resulting from such consultation is left up to the states parties involved, which should act in compliance with the spirit of the Treaty. This arrangement follows the current practice that the successive administrations of Japan claim to have been taking up in relation to Japan's non-nuclear three principles.

(5) Obligation to Cooperate with Energy

The 1992 Joint Declaration of the Denuclearization of the Korean Peninsula prohibits the possession of "nuclear reprocessing and uranium enrichment facilities." Many observers agree that application of such a 
prohibition to Japan would make it almost impossible to conclude the treaty at an early date because it has already invested for such activities for a long time as its national endeavor. However, the treaty might perpetuate an obvious imbalance between Japan and the Koreas with respect to securing energy unless some due consideration is taken regionally or internationally. The Model Treaty recognizes the importance of this problem and establishes the following obligation. "The Intrazonal States shall pursue and develop cooperation among themselves in good faith to secure stable and sustainable energy for each of the Intrazonal States."

\section{(6) Some Remaining Issues}

As I said earlier, the Mbolel Treaty is a point of departure for further discussion and deliberations. However, in giving shape to such a treaty, several important unresolved issues have been demonstrated.

One major problem is an embodiment of verification system. The verification system must fully utilize the capabilities of the IAFA. In addition, we should develop a regional verification system in a way that builds trust and cooperation among the nations of the region. The recently agreed Central Asia NWFZ Treaty (Semipalatinsk Treaty) has become the first treaty that adopts the provision to dblige state parties to conclude with IAEA and bring into force not only full-scope safeguards but also an Additional Protocol. Our model treaty follows suite to this example. Nevertheless it is good idea to develop additional regional system to complement international arrangement.

Another important issue is energy cooperation, and here we must be content with initiating a wide-ranging discussion. Formulating an agreement will take time and many obstacles must be overcome. I believe the deliberation on the problem is closely related to the intemational control of the nuclear fuel cycle that draws much attention recently.

Also, the matter of ships and aircraft suspected of carrying nuclear weapons will clearly require deeper discussion and experiential exchange within concemed researchers and citizens.

Although these issues and others are open for more deliberation, I would like to emphasize that rapid establishment of even a minimal Northeast Asia NWFZ will contribute greatly to peace and stability in the region. In this context, I believe that the No. 5 Working Group for Northeast Asia Peace and Security Mechanism set up in initial actions 
agreement at the Six Party Talk in February 2007 can be a reasonable venue to start negotiations for a NEA-NWFZ.

Table 1. CHRONOLGY

Proposals for a Northeast Asia Nuclear Weapon-Free Zone

\begin{tabular}{|l|l|l|}
\hline $\begin{array}{l}\text { March } \\
1995\end{array}$ & Endicott, et al. & $\begin{array}{l}\text { Limited N uclear Weapon-Free Zone (LN WFZ) } \\
\text { applicable to non-strategic nuclear weapon only. } \\
\text { C ircular LN WFZ consisting of a circular area with a } \\
\text { 2000-kilometer radius from a center point at the } \\
\text { Demilitarized Zone (D MZ) on the Korean Peninsula. } \\
\text { Later, Elliptic LN WFZ with its major axis extending } \\
\text { to part of Alaska }\end{array}$ \\
\hline 1995 & Andrew Mack & N WFZ involving the RO K, DPRK, Japan and Taiwan \\
\hline $\begin{array}{l}\text { March } \\
1996\end{array}$ & Kumao Kaneko & $\begin{array}{l}\text { Circular N WFZ consisting of a circular area with a } \\
\text { 2000-kilometer radius from a center point at the } \\
\text { Demilitarized Zone (D MZ) on the Korean Peninsula. } \\
\text { Obligations of the nuclear and non-nuclear weapon } \\
\text { states within the zone would differ from each other. }\end{array}$ \\
\hline $\begin{array}{l}\text { May } \\
1996\end{array}$ & Hiromichi Umebayashi & $\begin{array}{l}\text { Three Plus Three Arrangement involving three non- } \\
\text { nuclear weapon states (RO K, DPRK, Japan) and three } \\
\text { nuclear weapon states (China, Russia, US) }\end{array}$ \\
\hline $\begin{array}{l}\text { October } \\
1997\end{array}$ & Endicott, et al. & $\begin{array}{l}\text { LN WFZ involving non-nuclear weapon states (the } \\
\text { ROK, Japan and Mongolia (DPRK) ) as a Phase I }\end{array}$ \\
\hline $\begin{array}{l}\text { April } \\
2004\end{array}$ & $\begin{array}{l}\text { Hiromichi Umebayashi, } \\
\text { et al. }\end{array}$ & \begin{tabular}{l} 
Model Treaty of Three Plus Three Arrangement \\
\hline
\end{tabular} \\
\hline
\end{tabular}

